\title{
Editorial
}

\section{A taxonomy on banking regulation The renaming of this journal: From the JIBR to the JBR}

Financial markets have grown international over the last decades. Financial innovation and new technologies are indeed eroding geographic barriers. Regulation still remains nationally based, however, constrained by the domain of national jurisdictions.

Banking regulation refers to the establishment of rules, to the process of rulemaking and includes legislative acts and statutory instruments issued by the competent authorities nationally and supranationally, international rules (often 'soft law' in the field of banking and finance) and rules issued by self-regulatory organisations and private bodies or 'clubs', such as a cooperative bankers' association. Banking regulation draws from national, supranational and international sources. At a national level the competent authorities are (though this varies from country to country) the government, through the ministry of finance or Treasury, the central bank and the bank regulatory agency/agencies. At the level of the European Union, member states must comply with Treaty provisions (primary Community law) and with regulations and directives (secondary Community law). As acknowledged, the EU institutions - the Council, the Parliament and the Commission - play an important role in the EU legislative and regulatory process. ${ }^{1}$ At an international level, rules that emanate from international organisations suffer from the 'eternal' problem of international law: its effective enforcement.
The distinct force and effect of rules is important in order to understand the various sources of banking law and regulation.

Though many commentators use the terms 'regulation' and 'supervision' interchangeably, they are conceptually different. While regulation refers to the establishment of rules, supervision in a broad sense can be understood as a process with four stages or phases: licensing, authorisation (entry into the business); supervision stricto sensu; sanctioning; and crisis management, which comprises lender of last resort, deposit insurance and bank insolvency proceedings. ${ }^{2}$ Supervision in a narrow sense (ie supervision stricto sensu) refers to the oversight of financial firms' behaviour (in particular, risk control).

International banking regulation is a relatively recent phenomenon, born in response to the increasing internationalisation of the banking business. Though different in scope from national regulation, it is not that different in 'nature' (ie as regards the issues which need to be regulated) or in 'causality' (ie as regards the factors that trigger it). This latter point is important to understand the gestation and early development of this new phenomenon. International banking regulation is triggered or boosted in the aftermath of crisis situations, when the limitations or gaps of the system become more evident. International banking regulation, however, is not exempt from the eternal problem of international law: its effective enforcement. The rules 
'adopted' by the Basel Committee on Banking Supervision are only binding insofar as they are incorporated into national legislation.

With regard to the 'nature' of regulation, it is important to bear in mind that banking regulation has become more focused in recent decades on the lending function of commercial banks. ${ }^{3}$ Lending regulation typically combines mandatory rules, capital and liquidity requirements with a considerable degree of official protection. Today, however, bank lending represents a relatively small proportion of capital flows and international financing. As banks become more involved in trading and other securities activities, regulation and supervision need to address the challenges presented by the new lines of business, without creating a competitive disadvantage for banks vis-à-vis other financial intermediaries. Trading regulation is different from lending regulation; it is mainly based upon fiduciary rules, conduct of business, corporate governance, disclosure requirements and internal systems of controls and risk management; it often relies upon market discipline mechanisms and self-regulation. As banks continue their expansion into the securities business, the degree of official protection will diminish, and public mandatory rules and intervention need to be replaced by market supervisory mechanisms. Less official protection is the price banks must expect to pay in return for greater reliance on market discipline.

The development of international banking rules has often been a slow and patchy phenomenon because of the lack of a clear legal mandate, a reactive rather than a proactive character, and the vested interests national governments still have in the supervision of their financial sectors. The shift toward an international arena requires either the adoption of binding common rules or the centralisation of prudential supervisory and regulatory functions in a common authority to which responsibility in this area is transferred. International banking regulation has proceeded so far through the first route, within an 'informal forum', the Basel Committee on Banking Supervision. Regulation of banking at the EU level has also taken primarily the first route so far, designing common rules that set a least common denominator upon which the principle of mutual recognition operates.

In the case of the European Union, however, there is a clear legal mandate, and national governments have transferred responsibilities (including some of the attributes of sovereignty, most notably since the advent of EMU) to the EU institutions. In the banking sector, a substantial degree of market integration has been achieved in the EU through the adoption of a series of banking directives, even though there are still significant national differences with regard to tax laws, company laws and others that create opportunities for regulatory arbitrage.

The continuing (albeit spasmodic) integration of national markets and the new possibilities provided by the information revolution encourage the development of a common set of rules and indicative ratios, with a view to replacing the existing diversity of national regulations by internationally accepted standards. The techniques which have allowed the EC to advance in the development of a single market in financial services, mainly the principle of mutual recognition of national laws and regulations on the basis of prior minimum harmonisation of essential prudential rules, represent a paradigm of supranational regulatory convergence. Rule harmonisation at an international level could be best achieved by granting a formal mandate to the Basel Committee on Banking Supervision. A 'regulatory shift' from the national to the international arena would also 
require a much greater degree of consistency and coherence among different 'sectorial' regulators (banking, securities and insurance).

Financial institutions, though global in ambitions and often in international presence, are still subject to the control of national authorities. Banking remains a sensitive sector at the core of a nation's concerns. Regardless of how much a bank expands internationally, it is still recognised as a legal entity under the domestic laws of the place of incorporation. Constitutional and cultural differences, national habits and, at times, national oligopolies often obstruct international coordination, and may hinder other regional efforts, as evidenced by the EC experience

Banking regulation is the 'genus', international banking regulation is a 'species' within this genus. This journal wishes to attract - both in terms of readership and in terms of potential contributions - a wider range of papers on a greater variety of issues than those that can be strictly classified under the umbrella of international banking regulation. Hence, the change in denomination.

\section{Rosa M. Lastra \\ Senior Lecturer in International Financial and Monetary Law CCLS, Queen Mary, University of London e-mail: r.lastr@qmul.ac.uk}

\section{References}

(1) Article I-33 of the Treaty Establishing a Constitution for Europe refers to the legal acts of the Union and talks about European laws, framework laws, European regulations, European decisions, recommendations and opinions.

(2) For a further elaboration of these four stages with regard to banking supervision, see Lastra, Rosa (1996) 'Central banking and banking regulation', Financial Markets Group, London School of Economics, pp. 108-144.

(3) Early regulation was primarily about backing for note issue, cash and liquid asset ratios, transparency and capital. I am grateful to Charles Goodhart for observations on this point. 